Закалад М. А.;

Педан Ф. П.;

Романченко О. А.

Центр воєнно-стратегічних досліджень Національного університету оборони України імені Івана Черняховського, Київ

\title{
Підходи до формування основних характеристик АСУ логістичного забезпечення 3С України
}

Резюме. У статті проведено аналіз досвіду провідних країн світу щодо створення логістичної системи військового призначення, розглянуто програми розвитку (трансформації) військової логістики провідних країн світу та визначені напрями створення та розвитку автоматизованої системи логістичного забезпечення ЗС України.

Ключові слова: система логістики; концепція; автоматизована система управління; логістична діяльність; логістика; інформаційні технології; автоматизація процесів; оборонні ресурси.

Постановка проблеми. Вивчення питання щодо успішності та ефективності виконання заходів логістичного забезпечення (ЛЗ) бойових дій військ (сил) у світі за досвідом збройних сил провідних країн світу (ПКС) 3 метою вибору шляхів побудови власної автоматизованої системи управління (АСУ) ЛЗ для Збройних Сил (ЗС) України привело до висновку, що перспективні концептуальні підходи (відповідні директивні документи) зі створення сучасної АСУ ЛЗ ЗС України, мають грунтуватись на сучасних військових логістичних оперативностратегічних концепціях та передбачати у розробках широке використання передових досягнень у галузі науки i техніки для підвищення якості організації та управління Л3 збройних сил, застосування в системі управління інформаційних логістичних технологій для оборонних відомств, а також удосконалення форм i способів всебічного забезпечення бойових дій.

Аналіз останніх досліджень i публікацій. У фаховій літературі, що висвітлює проблеми становлення та розвитку логістики в Україні, переважно досліджується зарубіжний досвід застосування логістичних підходів на виробничих підприємствах [1]. Кількість літературних джерел, в яких досліджуються питання із застосування логістики та формування логістичних систем у військовій сфері, є невеликою.

Пропозиції щодо роз'вязання деяких проблем та основні положення становлення фундаментальних теоретичних положень формування логістичних систем висвітлюються у джерелах [1-3].
Однак низку питань щодо формування логістичних систем військового призначення i, зокрема, формування характеристик автоматизованих систем управління логістичного забезпечення військ (сил) належно не досліджено.

Тому тема дослідження основних напрямів щодо формування основних характеристик АСУ логістичного забезпечення Збройних Сил України $є$ актуальною.

Метою статті $\epsilon$ узагальнення досвіду провідних країн світу та формування рекомендацій щодо основних завдань АСУ логістичної системи військового призначення у ЗС України.

Виклад основного матеріалу. У сучасному розумінні концепція військової логістики є системою поглядів на планування i здійснення переміщення та забезпечення військ (сил). Концепція військової логістики у більшості провідних країн світу [4] складається 3 шести структурних елементів, які віддзеркалюються і в підходах до побудови ЛЗ ЗС України [5-7]:

поле діяльності - опрацювання проблем iз матеріально-технічного забезпечення $\mathrm{y}$ питаннях розбудови сектору безпеки держави, зміцнення обороноздатності та створення бойових спроможностей $3 \mathrm{C}$ України, забезпечення взаємодії силового блоку 3 економічним комплексом країни;

основні цілі-створення надійних механізмів задоволення потреб ЗС України в оборонних ресурсах, озброєнні, військовій техніці, матеріальному забезпеченні, предметах постачання, необхідних роботах (послугах) у ході повсякденної діяльності та майбутніх бойових діях; 
основні

принципи - це

правила логістики, а саме: своєчасність, повнота, надійність, раціональність, цілісність, системність, ієрархія, інтеграція,

формалізація;

логістичні

стратегії - застосування сучасних інноваційних логістичних IT-рішень для оборонних відомств, поліпшення якості логістичних процесів;

логістична

система - система матеріально-технічного забезпечення ЗС України, що $є$ у свою чергу підсистемою єдиної автоматизованої системи управління ЗС України;

специфіка діяльності - обумовлена завданнями, покладеними на силовий блок, 3С України, підрозділи військ (сил) за визначеними напрямами та в різних умовах обстановки.

Розглянемо детально один із ключових елементів концепції військової логістики принципи забезпечення військ (сил). Для створення більш об'єктивної картини поділимо принципи на дві групи та дамо їх характеристику: надійність;

основна група-своєчасність, повнота,

додаткова

інформаційна безпека, економічність, цілісність, ієрархічність, системний підхід, універсальність.

Принципи своєчасності, повноти i надійності визначають необхідність забезпечення військ (сил) відповідно до їх реальної потреби, у встановлений термін шляхом використання гарантованих діючих механізмів. Застосування цих принципів $\epsilon$ необхідною умовою створення належних умов для виконання військами покладених на них завдань.

Принцип стійкості. Логістичні системи військового призначення мають бути побудовані таким чином, щоб і в умовах впливу противника збройні сили безперервно забезпечувалися відповідними ресурсами 3 мінімальними втратами.

Принцип інформаційної безпеки припускає захищеність інформаційних ресурсів ЗС України і заходу щодо запобігання несанкціонованого доступу.

Принцип економічності означає пошук i використання менш витратних способів виконання логістичних завдань.

Принцип цілісності припускає функціональну інтеграцію (зв’язаність) процесів елементів системи логістичного забезпечення військ (сил) при їхній внутрішній структурній незалежності. Застосування цього принципу дасть змогу проводити оптимізацію взаємозалежних ресурсів системи ЛЗ ЗС України i забезпечувати зміну окремих елементів без порушення іiі структури в цілому.

Принцип ісрархічності припускає, що всі основні питання, пов'язані 3 матеріальнотехнічним забезпеченням військ (сил), мають вирішуватися шляхом організації ефективної взаємодії органів військового управління всіх рівнів відповідно до наданих повноважень і визначених обов'язків.

Принцип системного підxоду припускає розгляд питань забезпечення військ (сил), ЗС України у цілому. Застосування цього принципу дасть змогу об'єктивно визначати масштаби i ефективність проведених заходів забезпечення.

Принцип універсальності припускає розроблення і використання єдиних підходів до організації і управління логістичним забезпеченням військ (сил). Застосування цього принципу дасть змогу забезпечити методологічну єдність при організації i проведенні заходів щодо логістичного забезпечення ЗС України як відомчими підрозділами, так і організаціями економічного комплексу країни.

У провідних країнах світу системам матеріально-технічного забезпечення відводиться важлива роль у реалізації оперативно-стратегічних концепцій i програм розвитку та застосування ЗС, підтримання їх в постійній готовності до виконання поставлених завдань. Як наслідок, за цими рішеннями 3'явилися нові концепції розвитку систем управління $3 \mathrm{C}, \quad$ військові логістичні оперативно-стратегічних концепції, а також низка програм розвитку (трансформації) військової логістики [8], а саме:

- "Мережецентрична війна" (NCO/NCW Network Centric Operations/Warfare);

- "Мережецентричне матеріальнотехнічне забезпечення" (NCL Network Centric Logistics);

- “Об'єднана логістика" (JCL Joint Concept for Logistics);

- “Загальна видимість ресурсів матеріально-технічного забезпечення" (JTAV Joint Total Asset Visibility);

- "Цілеспрямоване матеріально-технічне забезпечення” (Focused Logistics);

- "Чутливе i швидко реагуюче матеріально-технічне забезпечення" (S \& RL Sense and Respond Logistics ); 
- "Всеохоплююча матеріально-технічна готовність" (360 Logistic Readiness) та інші.

Розглянемо основні положення військових логістичних оперативностратегічних концепцій $[8,9]$. Заходи військових логістичних концепцій та програм охопили всі види ЗС і етапи здійснення ЛЗ бойових дій військ (сил) від розгортання, постачання в ході ведення бойових дій до евакуації сил.

Метою цих заходів є:

- алгоритмічна та вартісна оптимізація процесів матеріально-технічного забезпечення (далі-МТ3);

- зменшення надмірності і дублювання;

- підвищення оперативної ефективності, надійності і гнучкості системи ЛЗ.

Особливістю заходів стало висунення на перший план, у матеріально-технічному забезпеченні, здійснення "операцій на основі ефекту" (effect based operations), які передбачають досягнення поставлених цілей за рахунок використання малочисельних сил ЛЗ.

спрямовані на:

Перераховані концепції та програми підвищення боєготовності військ (сил) та їх ресурсного забезпечення їх дій протягом тривалого часу;

збільшення

функціонування ланцюгів постачання, надійності постачання та його адаптивності до потреб бойових підрозділів;

скорочення часу військової техніки (далі-ОВТ), зменшення обсягів потрібних запасних частин та інше.

У програмах розвитку ЛЗ перераховані комплексні заходи, пов'язані 3 перетвореннями у сфері матеріальнотехнічного забезпечення, та їх зміст в цілому, визначають цілі стосовно досягнення належного ресурсного забезпечення оперативно-стратегічних планів військових дій.

У концепціях визначені основні пріоритетні напрями розвитку можливостей Л3 та автоматизованої підтримки процесів управління:

$$
\text { - повна реалізація }
$$

“об'єднаності” у розвитку системи

логістичного забезпечення;

- інтеграція АСУ МТЗ у загальну

систему планування військових дій;

- інтеграція всіх процесів матеріально-

технічного забезпечення в рамках єдиної бізнес-моделі та інформаційної архітектури 3С;

- оптимізація функціонування системи постачання матеріально-технічних засобів;

- відпрацювання структури, складу i порядку створення потенціалу логістичного забезпечення;

- забезпечення підтримки необхідного рівня боєготовності та бойових можливостей військ (сил) протягом всього часу, необхідного для вирішення поставлених завдань;

- реалізація ресурсної забезпеченості бойових дій згідно розроблених планів;

- раціоналізація потреб бойових підрозділів в ЛЗ;

- зменшення строків обробки i забезпечення точності виконання заявок на доставку предметів постачання;

- забезпечення своєчасної та точної доставки матеріальних засобів у 3С;

- здійснення автоматизованого планування процесу забезпечення транспортування, розгортання i бойових операцій угруповань сил;

- виконання періодичної або постійної оцінки ефективності витрат на логістичне забезпечення ЗС для подальшої оптимізації за різними варіантами розвитку системи ЛЗ;

- дослідження і розроблення процедур оптимального управління Л3.

Розглянемо більш конкретно одну 3 концепцій. "Об'єднана логістика" (Joint Logistics) [10], за якою створюється інтегрована в єдине середовище система матеріальнотехнічного забезпечення збройних сил матеріально-технічними ресурсами. Реалізація “об'єднаної логістики” здійснюється 3 метою синхронізації зусиль МТЗ ЗС, координованого і спільного використання відповідних ресурсів ЗС у складі міжвидових угруповань військ (сил).

У рамках єдиного середовища в ЗС ПКС діє створена об' єднана система логістики (Joint Logistics Enterprise), що являє собою багаторівневу та взаємопов'язану сукупність керівних органів МТЗ, підпорядкованих їм підрозділів матеріально-технічного забезпечення, постачальників матеріальнотехнічних засобів та послуг, пов'язаних єдиними цілями, концепціями, контрактами, угодами та іншими нормативно-правовими документами.

Ефективність зусиль “об” єднаної логістики” визначається оптимальним розподілом функцій між командуваннями видів 3С, управлінням тилу, іншими органами управління та підрозділами матеріальнотехнічного забезпечення, які й утворюють 
об'єднану систему матеріально-технічного забезпечення.

такі:

Функціями “об’єднаної логістики” є

матеріальне забезпечення угруповання

військ (сил);

технічне обслуговування та ремонт озброєння і військової техніки (далі - ТОРО);

транспортне забезпечення (розгортання

сил i перевезення матеріально-технічних засобів);

забезпечення особового складу

(продовольче, розквартирування і розміщення в польових умовах, забезпечення базування підрозділів, банно-пральне і речове обслуговування тощо);

управління контрактами 3 фірмамипідрядниками;

медичне забезпечення;

інженерне забезпечення;

знешкодження боєприпасів i утилізація.

У ЗС країн НАТО планується перехід від існуючої системи матеріально-технічного забезпечення ЗС до більш рухомої, заснованої на широкому використанні нових інформаційних технологій $[11,12]$. Ïi ефективність буде визначатися точним знанням місця розташування і переміщення матеріально-технічних засобів i служб, а також можливістю їх управління через “безшовну" систему підтримки прийняття рішень та зв'язку. Планування заходів “об'єднаної логістики” відповідно до системи адаптивного планування та керівництва здійснюється в рамках загального оперативного планування міжвидових операцій.

Висновок. Проведений аналіз показує, що для втілення досвіду провідних країн світу щодо створення систем логістики військового призначення та програм розвитку військової логістики в логістичну систему ЗС України необхідна реалізація таких напрямів розвитку АСУ ЛЗ ЗС України, як:

- повна ситуаційна обізнаність про ресурси (повноцінне охоплення ресурсів, оперативне відстеження наявності, місця розташування матеріальних запасів і засобів їх доставки) в режимі реального часу на основі єдиної бази даних та інформаційнокомунікаційного простору;

- своєчасне реагування на поточні та прогнозовані потреби угруповань сил, швидка i адресна доставка $\mathrm{i}$ розподіл засобів забезпечення 3 відмовою від завчасного створення значних запасів засобів матеріальнотехнічного забезпечення;

- повна інтеграція заходів з управління ресурсами і засобами матеріально-технічного забезпечення в ході бойових дій (операцій);

- гнучка адаптація системи матеріальнотехнічного забезпечення до умов реальної оперативної обстановки, а також досягнення найбільшої однорідності процесів функціонування АСУ логістичного забезпечення в режимі мирного i воєнного часу;

- ефективність і попереднє планування процесів технічного обслуговування і ремонту, забезпечення експлуатаційної надійності та ремонтопридатності.

Подальші дослідження доцільно спрямувати на вибір методів побудови АСУ логістичної системи військового призначення.

\section{СПИСОК ВИКОРИСТАНОЇ ЛІТЕРАТУРИ}

1. Амітан В.Н. Логістизація процесів в організаційно-економічних системах: монографія / В. Н. Амітан, Р. Р. Ларіна, В. Л. Пілюшенко. НАНУ Інститут економіко-правових досліджень. Донецьк: ТОВ “Юго-Восток, Лтд”, 2012. - 73 с.

2. Голиков Е. А. Управление логистикой. М.: Высшая школа, 2014. - 200 с.

3. Голдрат Э. М. Процесс непрерывного совершенствования / Голдрат Э. М., Кокс Дж. / Пер. с англ. Самсонов П. М. М.: Попурри, 2015. $496 \mathrm{c.}$

4. НАТО. Довідник. К: Основи. 1997. - 286 с.

5. Тарасенко А. В. Наукові підходи до визначення змісту категорії "матеріально-технічне забезпечення суб'єктів сектору безпеки й оборони" / А.В.Тарасенко // Європейські перспективи. - 2013. - № 7. - С. 54-59.

6. Романченко I. С. Моделювання систем матеріально-технічного забезпечення: монографія / I. C. Романченко, О. I. Хазанович, С. С. Трегубенко - Львів: НАСВ ЗС України, 2015. $-156 \mathrm{c}$.

7. Наказ про затвердження Основних положень логістичного забезпечення Збройних Сил України від 11.10.2016 № 522 [Копія] / МО України. - К.

8. NATO 2020: “Assured security; Dynamicengagement" - analysis and recommendations of the group of experts on a new strategic concept for NATO [Електронний pecypc]. Режим доступу: http://www.nato.int/strategicconcept/expertsreport.pdf.

9. The NATO Handbook [Електронний pecypc]. Режим доступу: http://www.freeinfosociety.com/ media / pdf/ 123.pdf.

10. Joint Logistics (JP 4-0) [Електронний pecypc]. Режимдоступу: $\quad$ http://www.globalsecurity.org/ military/ library/policy/dod/joint/jp4_0.pdf. 
11. Combat Service Support (FM 4-0) [Електронний pecypc]. - Режим доступу: http://tsg3.us/tnsg_lib/ unit_dig_lib/fm4_0.pdf.
12. Sustainment (FM 4-0) [Електронний ресурс]. Режим доступу: http://www.globalsecurity.org/ military/ library/policy/army/fm/4-0/fm4-0.pdf

Стаття надійшла до редакції 06.03.2018

Закалад Н. А.

Педан Ф. Ф.

Романченко О. А.

Центр военно-стратегических исследований Национального университета обороны Украины имени Ивана Черняховского, Киев

\section{Подходы к формированию основных характеристик АСУ логистического обеспечения ВС Украины}

Резюме. В статье проведен анализ опыта ведущих стран мира относительно создания логистической системы военного назначения, рассмотрены программы развития (трансформации) военной логистики ведущих стран мира и очерчены направления создания и развития автоматизированной системы логистического обеспечения ВС Украины.

Ключевые слова: система логистики; концепция; автоматизированная система управления; логистическая деятельность; логистика; информационные технологии; автоматизация процессов; оборонные ресурсы.

\section{N. Zakalad;}

F. Pedan;

O. Romanchenko

Center for Military and Strategic Studies of the National Defence University of Ukraine named after Ivan Cherniakhovskyi, Kyiv

Approaches to the formation of the main characteristics of ACS logistics support of the Armed Forces of Ukraine

Resume. The article analyzes the experience of the leading countries of the world regarding the creation of a logistic system of military use, examines the programs of development (transformation) of military logistics of the leading countries of the world, and outlines the directions of creation and development of an automated logistic support system of the Armed Forces of Ukraine.

Keywords: logistics system; concept; automated management system; logistics activities; logistics; information technologies; process automation; defense resources. 